This PDF is a selection from an out-of-print volume from the National Bureau of Economic Research

Volume Title: Topics in Empirical International Economics: A Festschrift in Honor of Robert E. Lipsey

Volume Author/Editor: Magnus Blomstrom and Linda S. Goldberg, editors

Volume Publisher: University of Chicago Press

Volume ISBN: 0-226-06083-7

Volume URL: http://www.nber.org/books/blom01-1

Conference Date: December 3-4, 1998

Publication Date: January 2001

Chapter Title: Inferring Relative Factor Price Changes from Quantitative Data

Chapter Author: Robert E. Baldwin

Chapter URL: http://www.nber.org/chapters/c10578

Chapter pages in book: (p. 47 - 70) 


\title{
Inferring Relative Factor Price Changes from Quantitative Data
}

\author{
Robert E. Baldwin
}

\subsection{Introduction}

As Travis (1964), Melvin (1968), and Vanek (1968) pointed out some thirty years ago, due to the indeterminacy of the commodity composition of trade in models with two or more factors and more goods than factors, it is useful to interpret the Heckscher-Ohlin theorem in terms of the exchange of a country's relatively abundant productive factors for its relatively scarce factors. Testing this theorem empirically now invariably involves calculating the factor content of the goods and services traded internationally. ${ }^{1}$ Some economists have also recently utilized measures of the factor content of trade to draw inferences about the causes of observed changes in factor prices. In addition, other authors have relied upon another important quantitative relationship in trade theory, namely, the behavior of factor proportions within and among industries, to draw conclusions about the causes of factor price changes.

In the spirit of Bob Lipsey's lifelong practice of integrating careful empirical work with sound economic theory, sections 2.2 and 2.3 of this paper first investigate, within the general equilibrium framework utilized by trade economists, the theoretical appropriateness of linking these quantitative measures to factor price changes. The conclusion reached is that only under special assumptions are such linkages justified. Deardorff and Staiger (1988), Deardorff (1997), and Panagariya (1998) have specified sets

Robert E. Baldwin is the Hilldale Professor of Economics, emeritus, at the University of Wisconsin-Madison and a research associate of the National Bureau of Economic Research.

1. Interestingly, the first major empirical test of the Heckscher-Ohlin theorem by Leontief (1953) also involved calculations of the factor content of trade. However, Leontief did not present a formal theoretical model justifying this approach. 
of assumptions under which the factor content of trade can be used to indicate the effects of trade on relative factor prices. Section 2.4 then presents empirical estimates of how trade may have affected the U.S. wage gap between more educated and less educated workers in recent years that are based on these assumptions. Section 2.5 summarizes the paper's main conclusions.

\subsection{The Implications of Changes in the Factor Content of Trade in Trade Theory}

Papers by Katz and Murphy (1992), Murphy and Welch (1991), and Sachs and Shatz (1994) illustrate the use of the factor content of trade to investigate the impact of trade on relative wages. Factor content calculations are utilized to estimate the effect of trade on the magnitude and sign of changes in relative demands for labor of different educational levels. Since the United States tends to export goods intensively using highly educated labor and to import goods intensively using less educated labor, they find that trade tends to increase the domestic demand for more educated labor and decrease the demand for less educated labor. Katz and Murphy (1992) find the impact of trade on the demand for all types of labor to be moderate in the late 1960s and 1970s, but quite significant in the 1980s. For example, they estimate that between 1979 and 1985, a period when the U.S. trade deficit was large and increasing, changes in trade across industries increased the relative demand for male college graduates by 0.55 percent, while reducing the relative demand for males who dropped out of school with eight to eleven years of education by 0.63 percent. They conclude that these trade-induced changes in relative demand moved in the correct direction to help explain the rising education differentials in the 1980s.

Consider the theoretical underpinning of these and similar statements in terms of the standard Heckscher-Ohlin model. To begin with the simplest version of this model, assume there are two freely trading countries, A and $\mathrm{B}$, who both produce two goods, $\mathrm{X}$ and $\mathrm{Y}$, utilizing two factors of production: less educated labor and more educated labor. Identical constantreturns-to-scale production functions are assumed for both countries, as are perfect competition, perfect internal mobility of factors, and identical homothetic preferences. Figure 2.1 depicts the trading equilibrium for the two countries in terms of the diagram first made familiar by Lancaster (1957) and Travis (1964) and later by Dixit and Norman (1980) and Helpman and Krugman (1985). Let $O_{\mathrm{B} 1}$ indicate the total quantities of more educated and less educated labor (measured from $O_{\mathrm{A}}$ ) that both countries possess initially; $O_{\mathrm{A}} Q$ (equals $O_{\mathrm{B} 1} Q^{\prime}$ ) the equilibrium total quantity of good $\mathrm{X}$ produced by both countries in equilibrium; and $O_{\mathrm{A}} Q^{\prime}$ (equals $O_{\mathrm{B} 1} Q$ ) the equilibrium total quantity of good Y produced by both coun- 


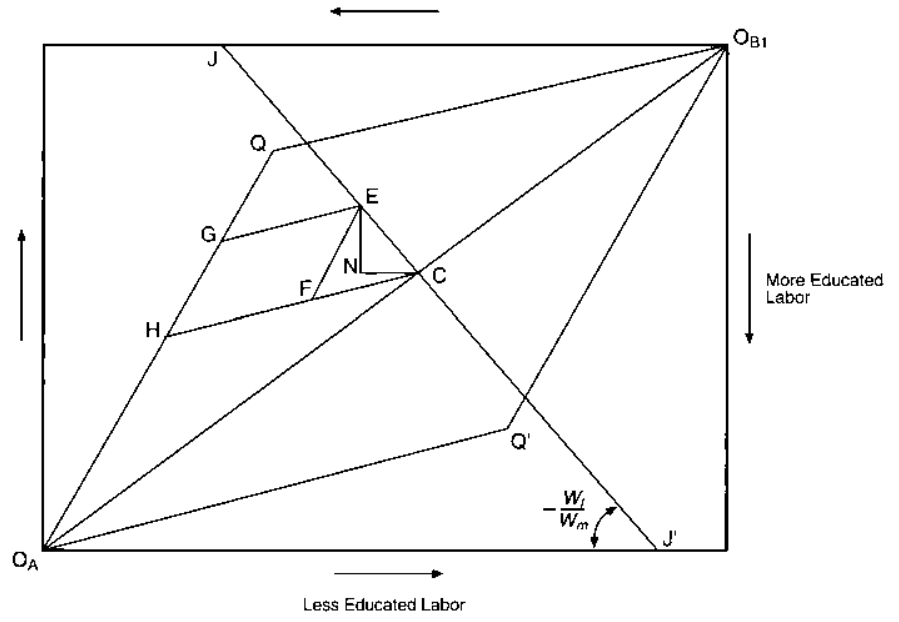

Fig. 2.1 Relationship between net factor content of trade and relative factor prices

tries. The slopes of these lines are the common equilibrium ratios of more educated to less educated labor used in producing the two goods.

Assume that $E$ describes the distribution of more educated and less educated labor between the two countries, with country A's endowments of these factors measured from $O_{\mathrm{A}}$ and country B's endowments from $O_{\mathrm{B} 1} \cdot{ }^{2}$ Since $E$ is above the diagonal, $O_{\mathrm{A}} O_{\mathrm{B} 1}$, country A is relatively well endowed with more educated labor compared to country $\mathrm{B}$, and country $\mathrm{B}$ is relatively well endowed with less educated labor compared with country A. Country A, therefore, exports the relatively more-educated-labor-intensive good, X, and imports the relatively less-educated-labor-intensive good, Y, while country B does the opposite. Since tastes are identical and homothetic, each country ends up consuming the two goods in the same proportions. Because each good is produced with the same factor proportions in both countries, this implies, in turn, that each country ends up, in effect, consuming more educated and less educated labor in the same proportions. Points on the diagonal $O_{\mathrm{A}} O_{\mathrm{B} 1}$, such as $C$, satisfy this condition.

Let the equilibrium levels of production of $\mathrm{X}$ and $\mathrm{Y}$ for country $\mathrm{A}$ be $O_{\mathrm{A}} G$ and $G E$, respectively, and the equilibrium levels of consumption of these goods, $O_{\mathrm{A}} H$ and $H C$, respectively. Consequently, $G H$ (equals $E F$ ) indicates the quantity of good $\mathrm{X}$ that country $\mathrm{A}$ exports as well as the amounts of more educated and less educated labor embodied in these exports. Similarly, $F C$ indicates the quantity of good Y that country B imports and the proportions of more educated to less educated labor embod-

2. It is assumed that $E$ lies within the parallelogram $O_{\mathrm{A}} Q O_{\mathrm{B} 1} Q^{\prime}$, so that factor price equalization between the two countries is achieved. 
ied in these imports. Thus, net exports of more educated labor are $E N$, while net imports of less educated labor are $N C$. Since the value of exports ( $=$ the quantity of more educated labor embodied in exports $\times$ the wages of more educated labor + the quantity of less educated labor embodied in exports $\times$ the wages of less educated labor) equals the value of imports (the quantity of more educated labor embodied in imports $\times$ the wages of more educated labor + the quantity of less educated labor embodied in imports $\times$ the wages of less educated labor) in the absence of capital transfers, it follows that the ratio of the net exports of more educated labor to the net imports of less educated labor (the slope of the line $J E C J^{\prime}$ ) equals the ratio of the wages of less educated labor to the wages of more educated labor. ${ }^{3}$

Next, consider the effects of a change in factor endowments in the two countries. To take the simplest case, assume that A's endowments remain unchanged but that the endowment of less educated labor in country B increases. This is depicted in figure 2.2, which is the same as figure 2.1 except that the point indicating the two countries' total endowments of the two factors shifts from $O_{\mathrm{B} 1}$ to $O_{\mathrm{B} 2}$. The point describing the distribution of the total endowments between the two countries, namely, $E$, remains unchanged, but the diagonal indicating points where the two factors are consumed in equal proportions shifts downward from $O_{\mathrm{A}} O_{\mathrm{B} 1}$ to $O_{\mathrm{A}} O_{\mathrm{B} 2}$. As is familiar in this simple model, the increase in country B's supply of its relatively abundant factor, less educated labor, causes its productionpossibilities curve for the two goods to shift outward in such a manner that, at any given price ratio of the two goods where both are produced, the output of the less-educated-labor-intensive good, Y, increases and the output of the more-educated-labor-intensive good decreases (the Rybczynski theorem). This, in turn, causes its offer curve of the less-educatedlabor-intensive good Y for the more-educated-labor-intensive good B to shift outward. If the offer curve of country A of good X for good $\mathrm{Y}$ is less than infinitely elastic, the relative international price of good $\mathrm{Y}$ will then fall, the wages of less educated labor will fall, and the wages of more educated labor will rise (the Stolper-Samuelson theorem). Associated with the decline in the wages of less educated labor compared to the wages of more educated labor will be a decrease in the ratios of more educated to less educated labor used in producing the two goods (to keep the figure from

3. In equation terms, $w_{m} X_{L m}+w_{l} X_{L l}=w_{m} M_{L m}+w_{l} M_{L l}$, or $-\left(w_{l} / w_{m}\right)=\left(X_{L m}-M_{L m}\right) /\left(X_{L l}-\right.$ $M_{L l}$ ), where $w_{m}$ and $w_{l}$ are the wages of more educated and less educated labor, respectively, while $X_{L m}-M_{L m}$ and $X_{L l}-M_{L l}$ are the net exports of more educated and less educated labor, respectively.

While increasing the number of goods beyond two in the two-factor Heckscher-Ohlin leads to an indeterminacy of the commodity composition of trade, it does not change this relationship between the factor content of trade and relative wages. 


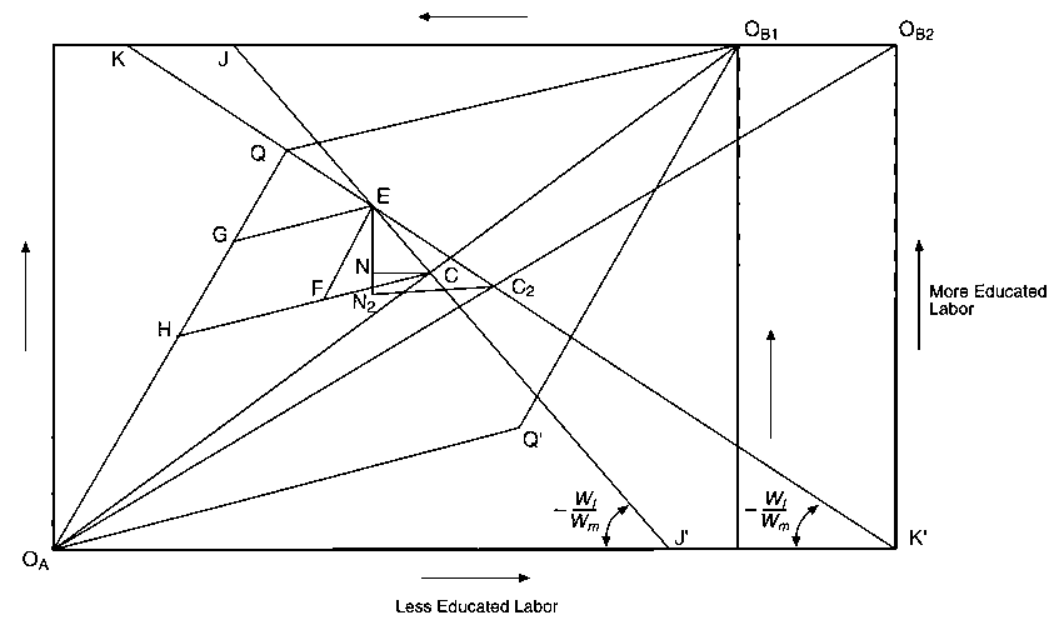

Fig. 2.2 Effects of change in factor endowments

becoming too cluttered, the resulting change in the parallelogram depicting the factor price equalization region is not shown).

Assume that $C_{2}$ is the new point of equal factor proportions consumption for the two countries, with the slope of the line between $E$ and $C_{2}$, namely, $\mathrm{KEC}_{2} \mathrm{~K}^{\prime}$, indicating the new lower ratio of the wages of less educated to more educated labor. As in the first situation, the ratio of country A's net exports of more educated labor, $E N_{2}$, to its net imports of less educated labor, $N_{2} C_{2}$, equals the equilibrium ratio of the wages of less educated to more educated labor. Thus, the change in relative wages can be inferred from the change in net factor proportions embodied in traded goods.

If, however, trade is not balanced, this relationship will no longer hold. Assume that $C$ is A's initial equilibrium consumption point when trade is balanced. Next assume that country A's citizens borrow funds from country $\mathrm{B}$ and increase their expenditures on both their import and export goods, thereby leading to an increase in imports and decrease in exports. ${ }^{4}$ A standard result of the literature on such transfers is that there will be no change in the terms of trade if tastes domestically and abroad are identical and homothetic so that the increased domestic spending on these goods is matched by decreased spending on them abroad. The new equilibrium point will still be on the diagonal $O_{\mathrm{A}} O_{\mathrm{B} 1}$ but closer to $O_{\mathrm{B} 1}$. Net exports of

4. The existence of the debt and the need to repay the loan will tend, of course, to reduce spending in the future, but the initial effect on expenditures will be positive. Murphy and Welch (1991) and Katz and Murphy (1992) take into account the increase in the trade deficit, but Sachs and Shatz (1994) do not. See Deardorff and Hakura (1994, 93-94) for a more detailed discussion of this issue. 
more educated labor and net imports of less educated labor will change, but the relative prices of these two factors remain unchanged.

As noted earlier, the papers cited in the beginning of this section draw conclusions about the importance of changes in trade on relative factor prices by comparing the changes in the proportions of different educated groups embodied in net exports to the domestic supplies of these factors. However, there is no unique relationship in the simple $2 \times 2 \times 2$ Heckscher-Ohlin model between changes in the ratios of factors embodied in trade to the total supplies of these factors, and changes in relative factor prices. For example, with a more inelastic international demand for good $\mathrm{Y}$ by country $\mathrm{A}$, the same decrease in the relative price of unskilled labor depicted in the shift in A's consumption of factors from $C$ to $C_{2}$ could have been achieved with a smaller relative increase in B's endowment of less educated labor. In this case the ratio of the wages of less educated to more educated labor would still be indicated by the slope of the line $K E C_{2} K^{\prime}$, but the new factor-consumption point in equilibrium would be on this line but closer to $E$. The ratios of country A's less educated and more educated labor embodied in net exports to the endowments of these factors will be less at this new consumption point than at $C_{2}$, although factor prices will be unchanged. ${ }^{5}$

Suppose that the increase in the endowment of less educated labor had occurred in country A rather than country B because of, say, immigration into country A. ${ }^{6}$ This will shift A's production possibilities curve such that, at any price ratio at which both goods are produced, the output of the less-educated-labor-intensive good Y will increase and the output of the more-educated-labor-intensive good $\mathrm{X}$ will decrease. This shift results in a decrease in country A's offer curve of good X for good Y so that, with an unchanged offer curve for country B, the price of the less-educatedlabor-intensive good $\mathrm{Y}$ will decline relative to the price of good $\mathrm{X}$ and, in accordance with the Stolper-Samuelson theorem, the wages of less educated labor will fall relative to the wages of more educated labor. The decrease in the wages of less educated labor relative to more educated labor (and thus the decrease in the ratio of more educated labor to less educated labor embodied in net exports) could be the same as in the case in which the increase in the supply of less educated labor occurred in country B. Thus, it is not possible to distinguish between these two cases by focusing only on the factor content of trade. However, when observers

5. The factor content of more educated labor in exports could even decrease compared with $C$ and thus give the incorrect signal concerning the direction of change of this factor price. Bhagwati and Dehejia (1994) also provide an example in which the ratios of factors embodied in net exports to the domestic supplies of these factors change, but relative factor prices do not.

6. The endowment point, $E$, in figure 2.1 will shift to the right by the amount of the increase in the endowment of less educated labor, for example, by $O_{\mathrm{B} 1} O_{\mathrm{B} 2}$. 
express concerns about the effects of globalization on relative U.S. wages, they usually have in mind the first case, in which the increased wage gap is brought about by an exogenous increase in foreign supplies of goods intensively using less educated labor. In the second case, the wider wage gap is due to a change in domestic labor supply conditions that have general equilibrium implications for trade flows.

Technological progress in country A can also affect relative wages and the factor content ratio in a manner that cannot be distinguished from changes in these variables due to changed conditions in country B. For example, more rapid neutral technological progress in industry $\mathrm{X}$ than in industry $\mathrm{Y}$ in country A (with technological conditions unchanged in country B), or more rapid less-educated-labor-saving technical progress in the $\mathrm{X}$ sector, both reduce the relative wages of less educated labor without any change in international commodity prices. Since both good X and good Y are produced with lower ratios of more educated to less educated labor as the relative price of less educated labor declines, the ratio of more educated to less educated labor embodied in net exports falls along with the relative price of less educated labor.

In summary, since exogenous shocks originating either within a country's domestic economy or abroad can produce similar effects on a country's factor content of trade in a general equilibrium setting, it is in general not possible to use this measure as a means of distinguishing between foreign versus domestic causes of shifts in relative wages. ${ }^{7}$ For similar reasons, measures of relative changes in the demand for different types of labor are also inadequate for attempting to determine the causes of changes in relative wages.

When the analytical framework is expanded to consider the more realistic situation of three or more factors and three or more goods, the ratio of the factor content of, say, more educated labor to less educated labor in net exports no longer can be used as a measure of the relative wages of these two factors. Consider, for example, a two-country, three-or-moregoods Heckscher-Ohlin model with three factors. In a depiction of the integrated free trade equilibrium, such as shown in figure 2.1 for two factors, the endowment point $E$ would be a point in three-dimensional space. The trading equilibrium $C$, at which both countries consume the three factors in the same proportions, would also be represented by a point in this space. The differences in the quantities of each of the three factors between $E$ and $C$ would give the net trade in each factor in moving from autarky to free trade. This trade in the factors would be indicated by moving along a straight line from $E$ to $C$. The relative prices of the three factors would be depicted as a plane that passed through both points $E$ and $C$;

7. Deardorff and Hakura (1994), Deardorff (1997), and Leamer (1994, 1996b) all stress this point. 
however, many different planes can be generated that rotate on a straight line between $E$ and $C$. Consequently, unlike the two-factor case, there is no unique relationship between the factor content of trade and relative factor prices. Depending on the nature of technology and consumer preferences, a particular content of the three factors in net exports can be the result of many different price relationships among the three factors and trading relationships among the three factors. Consequently, one cannot draw inferences about the price relationship between any two of the factors (e.g., more educated and less educated labor) from the amounts of these factors embodied in trade. The observed net imports of less educated labor may, for example, be the result of exporting more educated labor for less educated labor and also exporting capital for less educated labor. Comparing exports of more educated labor with total imports of less educated labor to infer the price of less educated labor for more educated labor would be incorrect under these circumstances. The same point holds with regard to comparisons of the proportions of these factors embodied in trade.

\subsection{The Implications of Changes in Factor Proportions within and among Industries in Trade Theory}

As noted in section 2.1, some economists stress the importance of within-industry shifts in factor proportions in contrast to between-industry changes in these proportions in reaching conclusions about the relative importance of different factors that may have brought about the increase in wage inequality. The paper by Berman, Bound, and Griliches (1994) illustrates this approach. Berman et al. investigate the relative importance of skill-biased technological change, increased trade, and increases in defense spending in explaining the shift in demand away from unskilled and toward skilled labor in U.S. manufacturing over the 1980s. Utilizing skill indexes based on the relationship between hourly earnings and the occupational classifications of blue-collar and white-collar workers, they first show that a significant part of the skill upgrading between 1973 and 1987 was due to a shift in the economy from production (blue-collar) workers to nonproduction (white-collar) workers. (They present evidence that shows production workers to be less skilled than nonproduction workers. $)^{8}$ They then decompose the increase in the proportion of nonproduction workers in U.S. manufacturing into that part due to their increased use within industries and that part due to the shift in production toward industries using high proportions of such workers. For explaining the shift in employment toward nonproduction workers, the authors argue that increases in international trade (as measured by the ratio of imports plus exports of 
manufactures to manufacturing shipments) and increases in military expenditures affect the skill composition of labor demand, primarily by shifting interindustry labor demand from industries intensive in the use of production workers to those intensive in the use of nonproduction workers. In contrast, they contend that biased technological change shifts the skill composition of labor demand within industries.

Berman et al. find that the within-industry component of the shifts in the demand for labor dominates the between-industry component. Furthermore, when they allocate employment in each of 450 industries to four sectors (domestic consumption, exports, imports, and defense procurement) and assume that imports replace employment in import-competing sectors, they find that the between-industry contribution of imports and exports to the rise in the share of nonproduction workers is small. Therefore, they conclude that the role of trade in shifting employment away from industries that intensively use production labor has been quite small.

The implications of these findings are best understood by analyzing the possible within-industry and between-industry factor proportion effects of various causes of the shifts in relative wages within a general equilibrium framework. Consider, for example, the effects of an increase in the share of international trade in GDP. While they do not discuss reasons that the ratio of a country's exports and imports to its output can increase, causes that seem to be consistent with what they have in mind are a reciprocal reduction in tariffs among countries or a general decrease in transportation costs. In these situations, trade could expand as a share of a country's GDP without any change in international prices of traded goods.

To examine the effects of such changes, again consider a standard two-factor (skilled labor and unskilled labor), two-good (a skilled-laborintensive good and an unskilled-labor-intensive one), two-country Heckscher-Ohlin model with homothetic preferences, in which the home country exports the skilled-labor-intensive good and the foreign country exports the other good. The endowments of the two types of labor are assumed to remain fixed in the two countries. Even if the reciprocal reductions of tariffs or the decrease in transportation costs do not change the international prices of the two goods, these changes will increase the relative domestic price of each country's export good. If we further assume that labor coefficients are fixed in each country, each country's output levels for the two goods will not change, nor will there be any change in the use of skilled versus unskilled labor within each country. Under these circumstances there will be no within-industry or between-industry effects on the use of skilled versus unskilled labor. However, as the relative domestic prices of the goods change, the real wages of skilled labor will increase relative to the wages of unskilled labor in the home country and fall in the foreign country, in accordance with the Stolper-Samuelson theorem.

If factor coefficients are not fixed, the output of the skilled-labor- 
intensive good will expand in the home country, and its output of the unskilled-labor-intensive good will decline. These shifts tend to increase the demand for skilled labor relative to that for unskilled labor. ${ }^{9}$ At the same time, in response to the changes in relative factor prices, there will be a substitution in production of unskilled labor for skilled labor in the home country, thereby decreasing the ratio of skilled labor to unskilled labor in the two industries. ${ }^{10}$ The opposite will take place in the foreign country. Thus, as trade expands, both within-industry and betweenindustry shifts in the relative use of skilled and unskilled labor occur. ${ }^{11}$ Both shifts take place concurrently.

Unskilled-labor-saving technical progress also brings about relative shifts in labor demand among and within industries. Consider, for example, the case in which technical progress that is saving of unskilled labor takes place to the same extent in both industries, in the sense that at unchanged factor prices the relative reduction in unit costs is the same in both sectors. ${ }^{12}$ Besides the within-industry shift toward the greater use of skilled compared with unskilled labor in both sectors, the output of the unskilled-labor-intensive industry (the import-competing sector) will increase relative to the output of the skilled-labor-intensive industry (the export sector) at given product prices. ${ }^{13}$ As long as the country is too small to affect its terms of trade, these within-industry and between-industry effects will not change relative factor prices. However, if the country is large in the sense of being able to affect its trading terms, the relative increase in the supply of the unskilled-labor-intensive good will tend to decrease the price of this good, thereby reducing the relative wages of unskilled workers. Nevertheless, if the labor coefficients are fixed under a given technology, there will be no further changes in relative outputs; but if substitution between the two factors is possible, these changes in the relative prices of the goods and factors will lead to further between-

9. The opposite will take place in the foreign country. For simplicity, it is again being assumed that the international price ratio does not change.

10. This is possible even though the country's total endowment of each factor remains fixed, since these ratios are weighted averages.

11. See Baldwin $(1995,27-30)$ for a diagrammatic explanation of this case and the example of unskilled-labor-saving technical progress discussed in the following paragraph.

12. In the standard Lerner diagram depicting unit value isoquants for the skilled-laborintensive and unskilled-labor-intensive goods, technical progress defined in this manner shifts both unit value isoquants based on constant product prices toward the origin so that the lower constant outlay line that must be tangent to both isoquants in equilibrium has the same slope as the constant outlay line tangent to the initial unit value isoquants. In other words, with this uniform technical progress across sectors, relative factor prices remain unchanged if product prices remain unchanged. Since the technical change is unskilled labor saving, the ratio of skilled to unskilled labor used in producing both goods is, however, greater at the new tangency points than initially.

13. In this two-factor, two-good model, the output of the unskilled-labor-intensive good must increase relatively more than that of the skilled-labor-intensive good at given product prices in order to employ fully the available endowment of unskilled labor. 
industry and within-industry shifts. The lower relative price of the unskilled-labor-intensive good will lead to a decrease in the output of this good relative to that of the skilled-labor-intensive good.

The relative decline in the wages of unskilled labor will also lead to a substitution of unskilled labor for skilled labor in each industry. Because of these offsetting forces, both the output of the skilled-labor-intensive good relative to the output of the unskilled-labor-intensive good and the ratio of skilled to unskilled labor used in producing the two goods could end up lower than their initial levels.

While this general equilibrium analysis supports the authors' conclusion that the increased use of skilled labor relative to that of unskilled labor within industries is consistent with unskilled-labor-saving technical progress' playing a dominant role in explaining the shift in relative wages in the 1980s, their factor use findings are not inconsistent with international trade's playing an important role in accounting for the increased wage inequality. As previously explained, the relative wages of unskilled workers could have fallen due to product price changes caused by increased trade without any (or with very little) between-industry or within-industry changes in the use of skilled versus unskilled labor. The increase in the wage gap brought about by increased trade under these circumstances could have been even greater than the increase associated with the withinindustry factor use shifts documented by Berman et al. that are consistent with the technology hypothesis.

\subsection{The Deardorff-Staiger Model for Inferring Relative Factor Price Changes from Changes in the Factor Content of Trade: An Empirical Analysis}

Deardorff and Staiger (1988), Deardorff (1997), and Panagariya (1998) show that, under special conditions, changes in relative factor prices can be inferred from changes in the factor content of trade. Deardorff and Staiger (1988) demonstrate that there is an equivalent autarky equilibrium associated with each trading equilibrium for a country under trading conditions with incomplete specialization in the following sense. ${ }^{14}$ If the factors embodied in the country's exports are subtracted from its initial factor endowments, and the factors embodied in the country's imports are added to its initial factor supplies (the factors embodied in trade being calculated with the country's own technology), then with the same prices of goods as prevailed in the trading equilibrium, a competitive production equilibrium exists in which the consumption of goods and factors is the same as in the trading equilibrium.

As these authors point out, the insight for this relationship is simply

14. It is not necessary to assume identical technologies across countries. 
that changing the endowment of factors in this manner provides the country with an endowment equal to the factor content of equilibrium consumption. Thus, the constructed autarky equilibrium merely endows the economy with the factors needed to produce what it had consumed with trade, thereby obviating the need for trade at the prevailing prices of goods and factors. Deardorff and Staiger (1988) then proceed by making the strong assumption that both preference and production functions are Cobb-Douglas. Cobb-Douglas production functions imply that each factor earns a constant share of the revenue of each industry, while CobbDouglas preferences imply that consumers spend a constant share of their total expenditures, $E$, on each good. In autarky, where consumers' expenditures on any good equal the revenue of the industry producing the good, the two relationships together imply that each factor's total income (from employment in all industries) is a constant fraction of consumer expenditures. Thus, letting $w_{i}$ be the return of the $i$ th factor, $L_{t}^{a}$ the endowment of this factor under autarky conditions, and $c_{i}$ the constant fraction for the factor, the following relationship holds:

$$
w_{i} L_{i}^{a}=c_{i} E .
$$

Next, consider two equilibria (numbered 1 and 2) that involve trade for this country. With trade, equation (1) does not apply directly. However, equilibrium factor prices with trade can be expressed in terms of what they would be without trade in an equivalent autarky equilibrium, the factor endowments of which are $B=L$ (the actual endowments) minus $S$ (the factors needed to produce what is exported less the factors needed to produce replacements for what is imported). Thus, letting $L^{0}$ be the actual factor endowments of the country (assumed to be the same in both trading equilibria), the price of factor $i$ in each trading equilibrium, $w_{i}^{2}$ and $w_{i}^{1}$, can be expressed in terms of total expenditures in each trading equilibrium, $E^{2}$ and $E^{1}$ (consumer preferences are assumed not to change), the unchanged endowment of the factor $L_{i}^{0}$, and the net contents of trade in the factor in the two trading equilibria, $S_{i}^{1}$ and $S_{i}^{2}$, as follows:

$$
w_{i}^{t}=\frac{c_{i} E^{t}}{L_{i}^{0}-S_{i}^{t}}, \quad t=1,2 .
$$

If we compare the price of factor $i$ in the two trading equilibria, we have

$$
\frac{w_{i}^{2}}{w_{i}^{1}}=\frac{E^{2}\left(L_{i}^{0}-S_{i}^{1}\right)}{E^{1}\left(L_{i}^{0}-S_{i}^{2}\right)} .
$$

If expenditures are the same in the two equilibria, the relationship can be simplified to

$$
\frac{w_{i}^{2}-w_{i}^{1}}{w_{i}^{1}}=\frac{S_{i}^{2}-S_{i}^{1}}{B_{i}^{2}} .
$$


Consequently, with unchanged Cobb-Douglas preferences and technologies for a country and unchanged expenditures and factor endowments between two trading equilibria, the relative change in the price of any factor can be expressed in terms of the change in the content of trade in the factor and the factor endowment of the equivalent autarky equilibrium of the number 2 trading equilibrium (which equals the factor content of consumption in this equilibrium).

One use of this relationship is to ask the following question: What would the gap in wages between highly educated and less educated workers have looked like in (say) 1987, if, given U.S. factor endowments, preferences, technology, and expenditures in that year, U.S. trade policy had been adjusted to hold the factor content of U.S. net exports (measured in U.S. techniques of production for 1987) at (say) their 1977 levels? ${ }^{15}$

The equation for calculating the change in the wage gap under this hypothetical scenario is

$$
\frac{w_{h}^{1987^{\prime}}-w_{l}^{1987^{\prime}}}{w_{l}^{1987^{\prime}}}=\frac{\left(1+\frac{S_{h}^{1977}-S_{h}^{1987}}{B_{h}^{1987^{\prime}}}\right) w_{h}^{1987}}{\left(1+\frac{S_{l}^{1977}-S_{l}^{1987}}{B_{l}^{1987^{\prime}}}\right) w_{l}^{1987}}-1,
$$

where the left side is the hypothetical wage gap between highly educated $(h)$ and less educated $(l)$ labor in 1987 as a ratio of the wages of less educated workers in the hypothetical 1987 economy that still exports in net factor terms what it had in 1977, $S_{i}^{t}$ is the observed content of net exports of the $i$ th factor (highly educated or less educated labor) in year $t(1977$ or 1987) measured in U.S. technologies of year $t$, and $B_{i}^{1987}$ is the U.S. endowment of factor $i$ in 1987 minus $S_{i}^{1977} \cdot{ }^{16}$ The difference between the

15. I am grateful to Robert Staiger for suggesting the use of equation (5) to test the effect of changes in the factor content of trade on relative wages.

16. In his characteristically witty and assertive style, Ed Leamer argues in his comment on this paper that, although one is neither making a technical error nor being illogical in empirically measuring the Deardorff-Staiger relationship between changes in the factor content of trade and relative changes in factor prices that holds under certain conditions, the researcher is "not making sense." According to Leamer, "the Stolper-Samuelson mapping of product prices into factor prices is the conceptually straightforward and direct setting in which to study how changes in trading opportunities are affecting U.S. wages. . . . Study prices, not quantities." However, since changes in domestic technological conditions affect wages independently from any resulting changes in product prices, it is necessary to assume no changes in domestic technology for it to be sufficient to focus only on the behavior of domestic prices in studying the forces affecting U.S. wages. One method of attempting to deal with the effects of changes in domestic technical conditions, which Leamer has utilized in other research (1996a), is to introduce measures of domestic changes in total factor productivity (TFP) into the analysis. However, as he also points out in that research, while changes in TFP directly affect wages, the price pass-through effects of these changes can range from none at all to a price pass-through equal to the productivity improvement. Arbitrary assumptions must be made about these pass-through effects in order to disentangle the price effects (and thus factor price effects) of changes brought about by changes in domestic technology from those brought about by other forces. Moreover, since these other forces 
hypothetical wage gap calculated by this formula and the actual wage gap can be interpreted as that part of the gap attributable to the actual change in trade between 1987 and $1977 .{ }^{17}$ Since the actual change in trade between these two years could be due to changes in U.S. factor endowments and preferences or technology as well as changes in foreign competition, it should be emphasized (see Deardorff 1997) that this equation does not isolate the effects of foreign competition on the wage gap.

The results of the calculation for the $1987 / 77$ period as well as for the 1977/67 period are presented in table 2.1. As indicated in the table, in 1987 the wages of highly educated workers (workers with thirteen or more years of education) exceeded those of less educated workers (workers with twelve years or less) by 50.3 percent, compared to 38.0 percent in 1977 . The hypothetical gap in 1987 would have been 48.0 percent if factor trade had been the same as in 1977. Thus, the change in trade between these years (whatever it causes) contributed 2.3 percentage points to the 12.3 percentage point increase (or 18.7 percent) in the increase in wage inequality.

If 1977 factor trade had been the same as in 1967, the gap hypothetically would have been 36.4 percent in contrast to the actual wage gap of 38.0. The interpretation is that the actual change in trade between 1967 and 1977 contributed 1.6 percentage points to the 1977 gap. The actual wage gap fell from 51.0 percent in 1967 to 38.0 in 1977, a decline of 13.0 percentage points. The change in trade reduced the narrowing of the wage gap by 11 percent $(=1.6 /[13.0+1.6])$.

In a recent paper, Deardorff (1997) extends the Deardorff-Staiger model beyond just Cobb-Douglas production functions and preferences to cover

include such things as changes in domestic relative factor endowments, it is necessary to label as a change in global trading opportunities "... something strictly internal to the US" (Leamer 1996a, 22). In short, it seems to me (and, judging by his own research, also to Leamer at a fundamental level) that without making arbitrary and not very reasonable assumptions about price pass-through effects and the meaning of changes in trading opportunities, one cannot adequately study the behavior of U.S. wages by focusing solely on changes in product prices. For an approach to disentangling the effects of changes in technology from changes in trade that is quite different from that followed in Leamer (1996a), see Baldwin and Cain (forthcoming).

17. It should be emphasized that equation (5) is not being used to calculate the effects of such ambiguous terms as "changes in trading opportunities," but simply to tell us what would have happened to the wage gap between two years if the United States had undertaken policies in the later year to stabilize the factor content of trade at its earlier level (assuming both that the changes to U.S. technology, endowments, and preferences that actually occurred between the two years would still have occurred, and that preferences and technology are Cobb-Douglas in form). As emphasized in the next sentence, one cannot attribute the difference between this hypothetical wage gap and the actual current wage gap to some specific factor such as changes in foreign competition. The calculations are helpful, nevertheless, in providing boundary estimates of what the U.S. wage effects would have been if the actual change in net exports had been due entirely to changes in foreign supply-and-demand conditions (and none at all to changes in domestic technology, tastes, or factor supplies) and there were Cobb-Douglas preferences and technology. 


\begin{tabular}{lcc}
\hline & $\begin{array}{c}1977=\text { Year } t, \\
1967=\text { Year } t-1\end{array}$ & $\begin{array}{c}1987=\text { Year } t, \\
1977=\text { Year } t-1\end{array}$ \\
\hline Hypothetical wage gap in year $t$, holding & & .480 \\
$\quad$ factor trade at year $t-1$ level & .364 & .503 \\
Actual wage gap in year $t$ & .380 & .023 \\
Gap in year $t$ attributable to change in trade & & \\
between year $t$ and year $t-1$ & .016 & .023 \\
\hline
\end{tabular}

Sources: Data on wages and proportions of workers by education groups and industry are from the March Current Population Surveys. Data on the value of exports and imports are from the seventy-nine industry (the two-digit level of classification) input-output tables published by the Bureau of Economic Analysis (BEA) of the U.S. Department of Commerce. These data are expressed in real terms, using the implicit price deflator for personal consumption expenditures from the National Income and Product Accounts. The Census Bureau's industry classification is concorded to the BEA's input-output industry classification. Employment and price data are from the Output and Employment Database of the Office of Employment Projections, Bureau of Labor Statistics. Estimates of the direct and indirect labor content of exports and imports are based on the BEA's 1977 and 1987 input-output tables.

all CES production functions and preferences. ${ }^{18}$ In doing so, he shows that the elasticity of a factor price (suitably normalized) with respect to its endowments is $-1 /$ (the elasticity of substitution). Therefore (approximating changes in logs by percentage changes), the percentage change in a factor price will be $-1 /$ (elasticity of substitution) times the change in factor content as a fraction of endowment. Modifying the changes in factor contents as a fraction of endowments in equation (5) by using substitution elasticities of, say, two and five rather than unity implies that the hypothetical wage gap in 1987 would have been 49.2 percent and 49.9 percent, respectively, rather than 48.0 percent, if factor trade had been the same as in 1977. Thus, with these substitution elasticities, the change in trade between these years accounts for only 8.9 percent and 3.2 percent, respectively, of the increase in wage inequality over this period.

The usefulness of such empirical estimates is a matter of judgment. Panagariya (1998) argues that the assumptions underlying the calculations are so stringent that the procedure cannot be considered a reliable guide to measuring the contribution of trade to wage inequality. He points out that empirical studies do not support the assumption that elasticities of substitution in production are the same across industries and, moreover, that there is no evidence of identical constant elasticity of substitution

18. Panagariya (1998) extends the earlier Deardorff-Staiger model in this manner. Krugman (1995) derives a related result. As Panagariya points out, Krugman confines his attention to infinitesimally small changes so that he is able to derive locally a reduced-form elasticity of substitution between skilled and unskilled labor without having to assume that all production and utility functions have identical constant elasticities of substitution. 
utility functions across goods. He also notes that the analysis requires the absence of any trade-induced technical changes and any trade-induced changes in factor endowments and tastes. These are important qualifications, but it seems to me that the underlying assumptions are sufficiently reasonable to provide another useful empirical means of roughly assessing the possible importance of increased foreign competition versus other factors in influencing the extent of wage inequality.

\subsection{Conclusions}

One main conclusion of this paper is that relative factor prices cannot, in general, be inferred from measures of the factor content of trade. In a simple two-factor Heckscher-Ohlin model with two or more goods, the ratio of the relatively abundant factor embodied in net exports to the relatively scarce factor embodied in net imports does measure the relative prices of the two factors, provided trade is balanced. However, this relationship breaks down when there are three or more factors. Measures of changes in the quantities of factors embodied in net exports to the domestic supplies of these factors are not reliable indicators of factor price changes, even in the simple $2 \times 2$ Heckscher-Ohlin model.

Another conclusion is that within-industry versus between-industry shifts in the relative factor proportions used in producing traded goods are not adequate indicators of the relative importance of the different exogenous factors affecting relative factor prices. In a general equilibrium model with factor substitution, exogenous changes in factor endowments, tastes, and technology all affect both the proportions of factors used within industries and the proportions of these factors used among industries. There is no unique relationship between the type of exogenous change and the relative importance of these two types of shifts.

As Deardorff and Staiger (1988) show, if technologies and preferences are Cobb-Douglas, factor prices are systematically related to factor endowments. Using the relationships that they derive and U.S. data on factor supplies, relative wages, and the factor content of trade, section 2.4 of this paper estimates that the change in trade between 1977 and 1987 contributed about 19 percent of the increase in wage inequality between these years. Between 1967 and 1977, the change in trade reduced the narrowing of the gap that took place between these years by about 11 percent. Using Deardorff's (1997) extension of the Deardorff-Staiger analysis to cover all constant elasticity of substitution technologies and preferences, it is also shown that the contribution of trade would have been about one-half or one-fifth as large as these figures if the substitution elasticities had been two or five, respectively. It should be stressed not only that the assumptions underlying this analysis are very stringent but that the portion attributable to trade could have been brought about by domestic changes in 
factor endowments, preferences, and technology as well as by increased foreign competition.

\section{References}

Baldwin, Robert E. 1995. The effect of trade and foreign direct investment on employment and relative wages. OECD Economic Studies 23 (winter): 7-54.

Baldwin, Robert E., and Glen G. Cain. Forthcoming. Shifts in relative U.S. wages: The role of trade, technology and factor endowments. Review of Economics and Statistics.

Berman, Eli, John Bound, and Zvi Griliches. 1994. Changes in the demand for skilled labor within U.S. manufacturing: Evidence from the Annual Survey of Manufactures. Quarterly Journal of Economics 109:367-97.

Berman, Eli, Stephen Machin, and John Bound. 1997. Implications of skill-biased technological change: International evidence. NBER Working Paper no. 6166. Cambridge, Mass.: National Bureau of Economic Research, September.

Bhagwati, Jagdish, and Vivek Dehejia. 1994. International trade theory and wages of the unskilled. In Trade and wages: Leveling wages down? ed. J. Bhagwati and M. Kosters, 36-75. Washington, D.C.: American Enterprise Institute.

Deardorff, Alan V. 1997. Factor prices and the factor content of trade revisited: What's the use? Research Seminar in International Economics, School of Public Policy. Discussion Paper no. 409. Ann Arbor: University of Michigan.

Deardorff, Alan V., and D. S. Hakura. 1994. Trade and wages: What are the questions? In Trade and wages: Leveling wages down? ed. J. Bhagwati and M. Kosters, 76-107. Washington, D.C.: American Enterprise Institute.

Deardorff, Alan V., and Robert W. Staiger. 1988. An interpretation of the factor content of trade. Journal of International Economics 24:93-107.

Dixit, Avinash, and Victor Norman. 1980. Theory of international trade: A dual, general equilibrium approach. Cambridge: Cambridge University Press.

Helpman, Elhanan, and Paul R. Krugman. 1985. Market structure and foreign trade: Increasing returns, imperfect competition, and the international economy. Cambridge: MIT Press.

Katz, Lawrence F., and Kevin Murphy. 1992. Changes in relative wages, 19631987: Supply and demand factors. Quarterly Journal of Economics 107 (February): $36-78$.

Krugman, Paul. 1995. Technology, trade, and factor prices. NBER Working Paper no. 5355. Cambridge, Mass.: National Bureau of Economic Research, November.

Lancaster, Kelvin. 1957. The Heckscher-Ohlin trade model: A geometric treatment. Economica, n.s. 24:25-28, 31-32.

Leamer, Edward E. 1994. Trade, wages and revolving door ideas. NBER Working Paper no. 4716. Cambridge, Mass.: National Bureau of Economic Research, April.

1996a. In search of Stolper-Samuelson effects on U.S. wages. NBER Working Paper no. 5427. Cambridge, Mass.: National Bureau of Economic Research, January.

1996b. What's the use of factor contents? NBER Working Paper no. 5448. Cambridge, Mass.: National Bureau of Economic Research, February.

Leontief, Wassily W. 1953. Domestic production and foreign trade: The American 
capital position re-examined. Proceeding of the American Philosophical Society 97:332-49.

Melvin, James R. 1968. Production and trade with two factors and three goods. American Economic Review 58 (December): 1249-68.

Murphy, Kevin, and Finis Welch. 1991. The role of international trade in wage differentials. In Workers and their wages, ed. M. Kosters, 39-69. Washington, D.C.: American Enterprise Institute.

Panagariya, Arvind. 1998. Trade and wages: The content of the factor content. Paper presented at the International Center of International Economics, College Park Md., University of Maryland, 16 February.

Sachs, Jeffrey D., and Howard J. Shatz. 1994. Trade and jobs in U.S. manufacturing. Brookings Papers on Economic Activity, no. 1: 1-83.

Travis, William P. 1964. The theory of trade and protection. Cambridge, Mass.: Harvard University Press.

Vanek, J. 1968. The factor proportions theory: The N-factor case. Kyklos 21 (4): $749-56$.

\section{Comment Edward E. Leamer}

According to Bill Gates's thesaurus, bob (the verb) means alternatively to prune or to duck, and bob (the noun) is a haircut.

In writing this comment, I have the pleasure to honor two other Bobs: Baldwin, the author of the article, and Lipsey, the Festschrift honoree. As an introduction to this comment, I remind the reader what $B o b$ means in international economics. It means careful and painstaking data work. It means getting the theory right. It means deep understanding. It is the opposite of duck. It refers to two distinguished economists who have insisted on a conversation about international economics that is adequately and appropriately informed by data. Because the subject of international economics has wisely become more empirical in the 1990s, now is a fine time to say thanks to our two Bobs for carrying this burden so long and so well.

With that as an introduction, the reader will not find it surprising to learn that there is not a single sentence in this paper with which I disagree (except those few sentences that must have slipped by Baldwin's screen!). Thus I think Bob Baldwin has the theory and the data right. If I could ask for something, it would be for more firmness. This trade and wages debate is very important, and we cannot allow it to be dominated by wrongheaded ideas. I am worried that Bob's light touch may leave the impression that the methods he comments on are not all that bad. To help out, here is my one-sentence version of this paper: Both the between-and-within accounting and the factor content calculations are completely pointless if they are intended to inform us whether trade is having an impact on wages.

Edward E. Leamer is the Chauncey J. Medberry Professor of Management and professor of economics and statistics at the University of California, Los Angeles, and a research associate of the National Bureau of Economic Research. 


\section{Between-and-Within Calculations}

Let's first dispose of the between-and-within studies initiated by Berman, Bound, and Griliches (1994). They conclude that it is skill-biased technological change, not trade, that is driving the increase in the premium for skills because of two reasons: (1) The ratio of nonproduction to production workers has been on the rise overall in the United States, even as the ratio of wages has risen. If trade were the driver, one would expect the input use of the cheaper factor to increase, not to fall. (2) This shift toward nonproduction workers occurs mostly within sectors, and not much between sectors. If trade matters, it does so by altering the sector composition of output. Since the big shifts have been within sectors, then it is technology, not trade, that matters. (Wrong and/or misleading statements are in italics.)

As Bob Baldwin correctly points out, there is nothing about our trade models that allows the conclusion that trade affects only the sectoral composition of employment, and not the within-industry mix of inputs. The basic theoretical logic of this between-and-within calculation is therefore faulty. However, repeating the theory doesn't seem to carry the day. Maybe some data will do the job. Figure 2C.1 illustrates the facts for the apparel sector: rising ratio of nonproduction to production workers and rising rela-

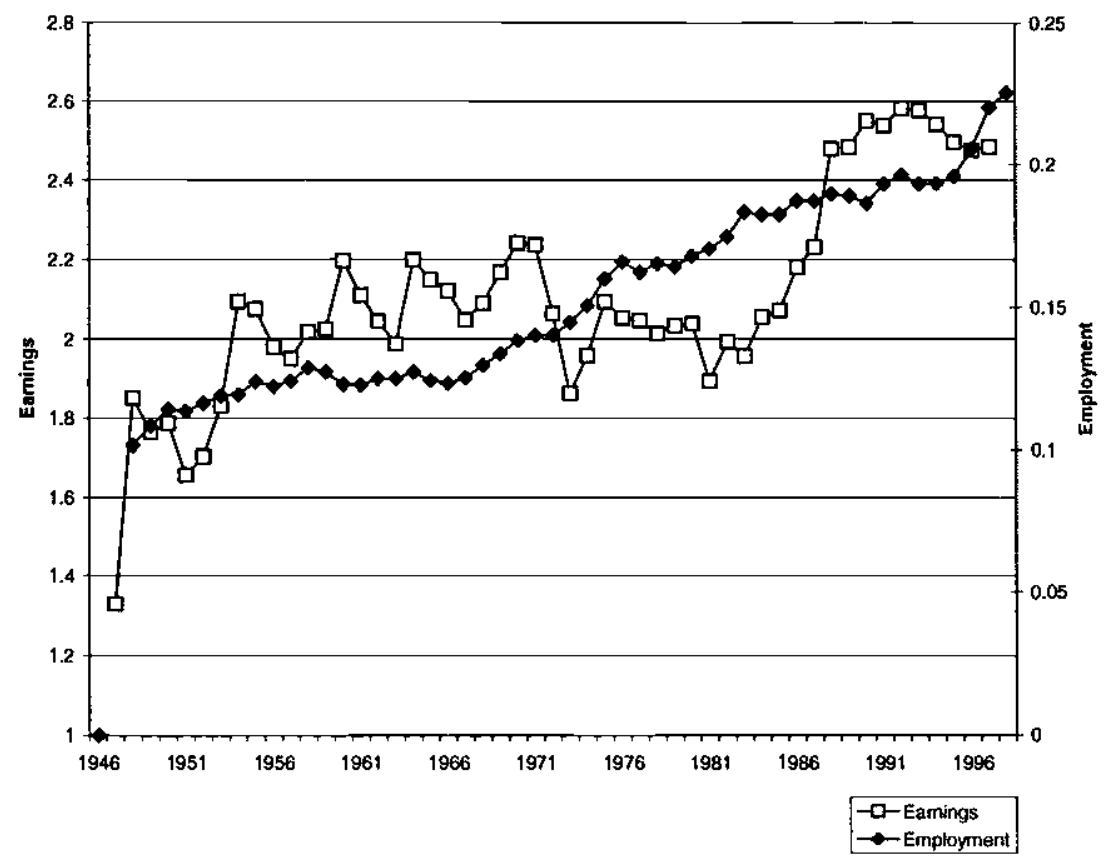

Fig. 2C.1 Apparel sector: ratios of nonproduction to production, employment and earnings 


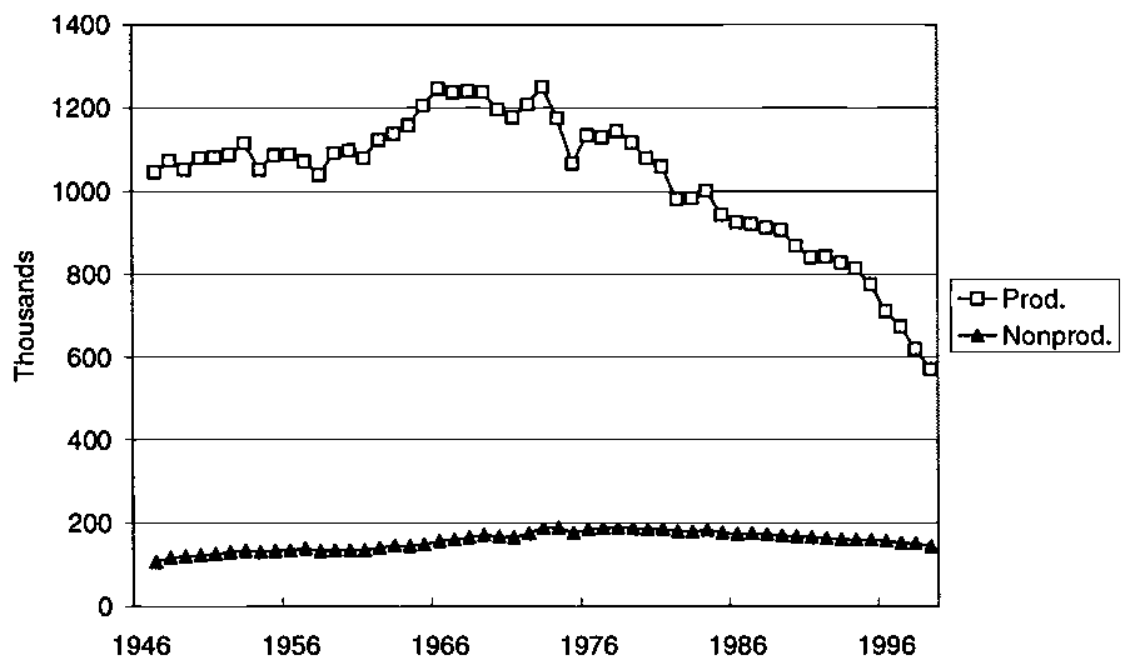

Fig. 2C.2 Production and nonproduction workers in apparel

tive wages. This must be technology, right? Wrong. Figure 2 C. 2 shows that the rise in the ratio of nonproduction jobs to production jobs in apparel, which began in the early 1970s, is due to a dramatic reduction in production jobs. This coincides with a big increase in imports (not shown). Thus faced with cheap apparel imports from low-wage countries, U.S. employers had three options - lower U.S. wages, raise U.S. productivity, or move the production jobs to Asia. They opted for some of all of these. Thus the within-industry increase in the ratio of nonproduction to production jobs, and the within-industry increase in the wages of nonproduction workers compared with production workers, were both caused by trade, not by technology.

\section{Factor Content Calculations}

The factor content calculations are a more difficult dragon to slay. Again, to focus the mind, I display in figure 2C.3 data on the factor content of U.S. trade computed by Leamer (2000). What exactly should we infer from the facts that until the 1980s, the labor embodied in U.S. trade was a very small fraction of the U.S. labor supply, and that in the 1980s, imports of high-school hours as a fraction of U.S. supply rose to almost 8 percent? From numbers like these, Katz and Murphy (1992) report, "Table VII presents the changes in relative labor demand predicted by changes in international trade in manufactures. ... The table indicates that the effects on relative labor demands of trade were quite moderate until substantial deficits developed in the 1980s. The adverse effects of trade on relative labor demand are concentrated on high school dropouts" (p. 65); and "De- 


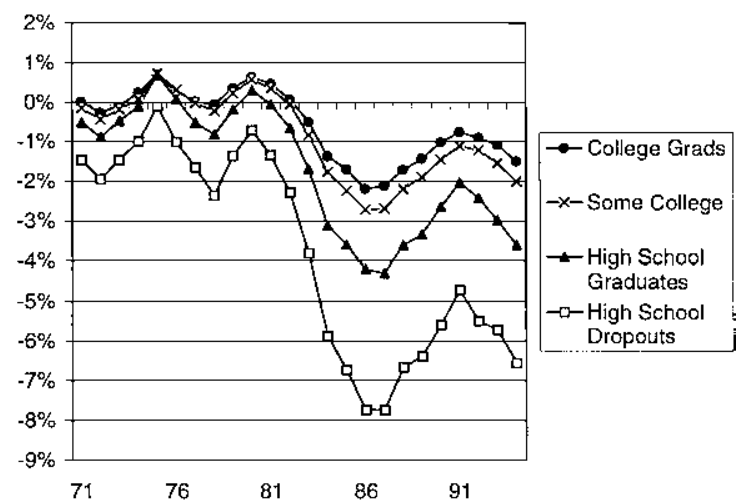

Fig. 2C.3 Hours worked embodied in trade: percent of U.S. hours Source: Leamer (2000).

mand shifts arising from changes in international change in manufacturing only start to be of quantitative significance with the appearance of large trade deficits in the 1980s" (p. 77). I don't think these conclusions are valid, and I don't think that Bob Baldwin does, either. But Baldwin's paper seems to have been written both by "Bob" and by some alien force that I will call "Bub."

For example, Bob writes, "The conclusion reached is that only under special assumptions are such linkages justified" (my italics), but Bub does it anyway: "Section $2.4 \ldots$. presents empirical estimates of how trade may have affected the U.S. wage gap between more educated and less educated workers in recent years that are based on these assumptions." Bob cautions again, "Panagariya (1998) argues that the assumptions underlying the calculations are so stringent that the procedure cannot be considered a reliable guide to measuring the contribution of trade to wage inequality." But Bub replies "Between 1967 and 1977, the change in trade reduced the narrowing of the gap that took place between these years by about 11 percent." Fortunately, Bob gets the final words: "It should be stressed not only that the assumptions underlying this analysis are very stringent but that the portion attributable to trade could have been brought about by domestic changes in factor endowments, preferences, and technology as well as by increased foreign competition."

$\mathrm{I}$ think Bob is right and Bub is wrong. I don't mean that Bub is making a technical error. The physicist Neils Bohr would explain to Bub: "You're not making sense. You're just being logical." Likewise, Deardorff and Staiger.

Here is the basic point: The Stolper-Samuelson mapping of product prices into factor prices is the conceptually straightforward and direct setting in which to study how changes in trading opportunities are affecting 
U.S. wages. One implication of the Stolper-Samuelson mapping is that events (such as the U.S. deficit in the 1980s) that do not alter technologies or relative prices of tradables have no effect on U.S. wages. Study prices, not quantities. Thus, the increase in the imports of labor inputs in the 1980s evident in figure 2C.3 doesn't mean that trade was affecting wages in the 1980s. Likewise, the small values of the factor contents in the 1970s don't mean that U.S. wages were unaffected by global trading opportunities, or by changes thereto. On the contrary, relative apparel and textile prices declined by 30 percent in the 1970s, and that relative price change, if the theory is correct, must beget wage changes.

While we are on the subject of "small," I remind the reader that there is an active literature in international economics (Trefler 1995; Gabaix 1997) that is attempting to explain why the factor contents are so small, not just for the United States but for most other countries as well. Until we figure out what is the best model for explaining why the factor contents are so small, I think it is very unwise to draw any conclusions from the fact that they are small.

If you want a full meal, not just a taste, visit Leamer (2000).

In conclusion, I am fond of saying that theories are neither true nor false; they are sometimes useful and sometimes misleading. Students in my class who have been studying hypothesis testing in econometrics are completely perplexed by this idea, but they feel better when I tell them that economists are neither right nor wrong-they are sometimes useful, and sometimes misleading.

Thanks, Bob, and thanks, Bob.

\section{References}

Berman, Eli, John Bound, and Zvi Griliches. 1994. Changes in the demand for skilled labor within U.S. manufacturing: Evidence from the Annual Survey of Manufactures. Quarterly Journal of Economics 109:367-97.

Gabaix, Xavier. 1997. The factor content of trade: A rejection of the HeckscherOhlin-Leontief hypothesis. Harvard University Working Paper.

Katz, Lawrence F., and Kevin Murphy. 1992. Changes in relative wages, 19631987: Supply and demand factors. Quarterly Journal of Economics 107 (February): $36-78$.

Leamer, Edward E. 2000. What's the use of factor contents? Journal of International Economics 50 (1): 17-50.

Trefler, Daniel. 1995. The case of the missing trade and other HOV mysteries. American Economic Review 12:1029-46. 
